\title{
Physico-Chemical Properties of Cake and Oil from three Castor Bean Accessions (Ricinus communis L) Grown in the Field in two Agroecological Zones of Northern Cameroon
}

\author{
MEGUENI Clautilde ${ }^{a}$, TCHUENTEU TATCHUM Lucien*a, NOUBISSIE Eric ${ }^{b}$ \\ DEROGOH WAY Néhémie ${ }^{\mathrm{a}}$, NJINTANG YANOU Nicolas ${ }^{\mathrm{a}, \mathrm{c}}$ \\ ${ }^{a}$ Department of Biological Sciences, Faculty of Sciences, University of Ngaoundéré-Cameroon; \\ ${ }^{b}$ Department of Chemical Ingenery, Institute University of Technology, \\ University of Ngaoundéré-Cameroon, \\ ${ }^{c}$ Department of Food Sciences and Nutrition, National School of Agro-Industrial Sciences, \\ University of Ngaoundéré-Cameroon \\ *tatchumlucien@yahoo.fr
}

\begin{abstract}
In the perspective to valorize Cameroonian castor bean (Ricinus communis L), physico-chemical properties of oil and cake from seeds of three accessions of this plant originated from the Sudano-sahelian and Sudano-guinean zones of Cameroon were assessed. Seeds oil extracted by soxhlet method using hexane exhibited contents varying significantly $(p<0.05)$ with the agroecological zone and castor bean accession. Seeds oil content ranged from $44.35 \pm 0.22$ to $53.65 \pm 0.30 \%$. Nitrogen content of castor cake varied significantly $(p<0.05)$ from $1.80 \pm 0.16$ in Soudano-sahelian zone to $4.59 \pm 0.30 \mathrm{~g} / 100 \mathrm{~g}$ DM in Sudano-Guinean zone. Potassium and phosphorus had mean values of $1.48 \pm 0.25$ and $0.13 \pm 0.05 \mathrm{mg} / 100 \mathrm{~g}$ DM respectively. The most abundant fatty acid in the oil was ricinoleic acid with mean value range of $62-67 \%$. In conclusion Cameroonian Castor Oil may play a role in the chemical industry market while the cake may be useful in agriculture as biological fertilizer or as folder for animal nutrition, but it toxicity needs to be investigated.
\end{abstract}

Keyword: Ricinus communis L., seeds oil, castor cake, physico-chemical properties, Cameroon.

\section{INTRODUCTION}

Ricinus communis Linn (Euphorbiaceae) or castor bean is a small tree widespread throughout the world ${ }^{[1]}$. It is a culture of great social appeal in Brazil by intensive use of work man ship in the field and allows for intercropping with other crops as beans, groundnuts or maize ${ }^{[2,3,4]}$. In addition, castor bean cultivation is encouraged in areas of low water availability. Castor bean has recently been highly rated as a source of raw material (oil) for biodiesel production ${ }^{[5]}$, due to its high oil content $(25-55 \%)$. Castor oil is also a raw material for paints, coatings, inks, lubricants and wide variety of other products. It is also used as laxative in human medicine ${ }^{[6]}$. Another product formed from the modification of castor oil is the sulfated castor oil which acts as an active wetting agent and is used intensively in dyeing and in finishing of cotton and linen ${ }^{[7]}$. The major producing countries are Brazil, China, India and the countries of the former Soviet Union ${ }^{[8]}$. India alone exports $80 \%$ of castor oil and therefore largely dominates the market. Castor oil is a triglyceride of various fatty acids which consist of ricinoleic acid (approximately 80-90\%), some linoleic (3-6\%), oleic (2-4\%) and other saturated (1-5\%) fatty acids ${ }^{[9]}$. Ricinoleic acid $\mathrm{C}_{18} \mathrm{H}_{34} \mathrm{O}_{3}$, is structurally known as cis-12hydroxyoctadeca-9-enoic acid, a 18-carbon hydroxylated fatty acid having 1 double bond ${ }^{[10,11]}$. Many publications reported that ricinoleic acid is a major components in castor oil and its level varied from one agroecological zone to another $89.2-94.9 \%^{[12]}, 70-90 \%{ }^{[13]}, 87-90 \%{ }^{[14]}, 89 \%^{[7]}$ and $90.2 \%{ }^{[10]}$. The industrial potential of castor oil relies on its high content of ricinoleic acid. Based on its industrial potential and the role it actually plays in sub-Saharan area not only in human medicine, but also in reduction of desert progression, castor bean may play a role in poverty alleviation in rural areas, but the data on their oil and fatty acid contents are very scarce. In addition there is limited information on the valorization of the cake, a by-product that derived from castor oil extraction.

Pressing one ton of castor beans for oil extraction produces around $550 \mathrm{Kg}$ of cake, but this value can vary with seed oil content and oil extraction process ${ }^{[15]} \cdot{ }^{[16]}$ investigate the proximate analysis of castor cake from Nigeria and reported that it contains 5.6, 27.22, 61.47, 23.61, and $72 \mathrm{mg} / 100 \mathrm{~g}$ of 
dry matter of phosphorus, calcium, magnesium, potassium and iron respectively. ${ }^{[17]}$ reported that nitrogen content of castor cake varies from 6 to $9 \%$. Castor bean cake has been investigated for its biological action as fertilizer, fungicide, in plant-parasitic nematode control, in recovery of depleted soils and as raw material for ethanol production ${ }^{[17]}$.

Cameroon has the potential to produce castor oil which could contribute to alleviate poverty in rural areas, since the plant is being extensively used in sudano area for live hedge, oil as human food and the stem for construction of house roofing ${ }^{[18]}$.

In addition, the grains are sold nationwide for human medicine. Unfortunately no information exists on the physicochemical properties of oil and cake, since these parameters are determinant for the trade and market. Studies on Cameroonian Castor bean accessions evaluated the variability for grain and yield related traits in two savannah agro-ecological zones and the effect of association of these plants with other crops in growing parameters ${ }^{[2,19]}$.

The lack of data on physicochemical properties seems to be disabilities for the appreciation of these Cameroonian castor bean accessions that could present interesting potentials useful in industrial, agricultural or breeding purposes.

Therefore, this work aimed to determine the physicochemical characteristics of the seeds, oil and cake from three Cameroonian Castor bean accessions (Motso 1, Motso 2 and Ndoutourou) grown in the field in two agro-ecological zones of Northern Cameroon.

\section{MATERIAL AND METHODS}

\subsection{Castor Bean Seeds and their Origin}

Seeds of three Cameroonian castor bean accessions (Motso 1, Motso 2 and Ndoutourou) were used for this study. These seeds were obtained in experimental farm from Ngaoundere (in the Sudano Guinean zone) and Maroua (Sudano Sahelian zone) ${ }^{[2]}$. Seeds were cleaned by hand picking to discard damaged ones, packaged and stored for physicochemical analysis ${ }^{[20]}$.

\subsection{Determination of Physical Characteristics of Seeds and Moisture Content}

The individual dimension of seeds such as length, width, thickness and weight were evaluated on 100 seeds sampled for each accession and agro-ecological zone. A sample of 100 dry seeds per treatment was used for moisture content analysis ${ }^{[21]}$. The seeds weight was evaluated by an electronic balance (Sartorius, Prodilab, France), with 0.001 sensitivity. Length, width and thickness are measured using micrometer gauge reading (of $0.01 \mathrm{~mm}$ sensitivity).

\subsection{Oil Extraction}

Seeds were decorticated and milled into fine powder: $5 \mathrm{~g}$ of powder were then oven-dried at $105^{\circ} \mathrm{C}$ for 1 hour. The oil was extracted using hexane as solvent ${ }^{[22]}$. In the procedure, samples were refluxed for 6 hours in mild temperature $\left(60^{\circ} \mathrm{C}\right)$ in a Soxhlet extractor. The solvent was then evaporated using rotary evaporator. Finally the extracted oil was kept in an oven at $60^{\circ} \mathrm{C}$ for $30 \mathrm{~min}$ before accurately weighed. The cake obtained after seeds oil extraction was kept in a closed container for subsequent proximate analysis.

\subsection{Physicochemical Analysis of Castor Oil}

Mass density expressed in $\mathrm{g} / \mathrm{mL}$ is defined as its weight per unit volume. It was determined using a $2.5 \mathrm{~mL}$ volumetric glass densitometer (with precision measuring 0.0005 units). Viscosity expressed in mps was determined on a sample of $200 \mathrm{~mL}$ in a vessel using rheometer brand Stresstech (Rheologica Instruments AB, Sweden). Iodine, acid and saponification indexes were determined using standard methods ${ }^{[23]}$. Fatty acid composition was determined by gas chromatography after preparation of methyl esters in a methanol solution of $\mathrm{BF}_{3}$ to $8 \%$ according to ${ }^{[23]}$ method.

\subsection{Physicochemical Characterization of Castor Cake}

For the characterization of the raw material, the cake was submitted to classical analyses. Concerning moisture content determination ${ }^{[23]}$, castor cake samples $(5 \mathrm{~g})$ were weight in crucible and submitted to oven-drying at $105^{\circ} \mathrm{C}$, until obtaining a constant weight. Nitrogen content was determined after sulfuric acid digestion and colorimetric determination of Nitrogen using the ${ }^{[24]}$ method.

Determination of organic matter content was done by aching the powder at $550^{\circ} \mathrm{C}$ for $3 \mathrm{~h}^{[21]}$ and the 
Physico-Chemical Properties of Cake and Oil from three Castor Bean Accessions (Ricinus communis L.) Grown in the Field in two Agroecological Zones of Northern Cameroon

ash residual was used for some mineral determination according to ${ }^{[25]}$. Quantification of potassium, phosphorus, sodium, sulfur and iron was carried out by flame spectrophotometry (Perkin Elmer Spectrophotometer HGA 700). The concentrations of the standards and samples are calculated from the absorbance values by linear regression equations.

The conventional conversion coefficient of nitrogen in protein (6.25) is used to determine protein content ${ }^{[26]}$. The crude protein content is therefore evaluated: $6.25 \times \mathrm{Q}(\mathrm{g} / 100 \mathrm{~g} \mathrm{DM})$ where $\mathrm{Q}$ is castor cake nitrogen content. The results are the average of three tests.

\subsection{Statistical Analysis}

Means and Data were submitted to analysis of variance (ANOVA) and when the difference was significant $(\mathrm{P}<0.05)$, a Duncan multiple range tests was performed to compared means. The statistical package "Statgraphics Plus", version 5.0 (Sigma Plus, Calif., USA) was used for this propose.

\section{RESULTS AND DISCUSSION}

\subsection{Physical Characteristics of Castor Bean Seeds}

Table 1 shows the analysis of variance (ANOVA) on physical characteristics of castor bean seeds. This table decomposes the variability of each variable depending on agro-ecological zone and castor bean accession. It appears that all variables analyzed (weight, length, width, thickness) varied significantly $(\mathrm{p}<0.001)$ according to the accession and / or agro-ecological zone. There are positive and significant correlation between length and width $(\mathrm{r}=0.97 ; \mathrm{p}<0.05)$, length and thickness $(\mathrm{r}=$ 0.96; $\mathrm{p}<0.05)$ and length and weight $(\mathrm{r}=0.81 ; \mathrm{p}<0.05)$ of seeds from Cameroonian castor bean used in this study.

Table1. Table of ANOVA of Accessions and Agroecological Zone Effects on Physical Characteristics of Seeds

\begin{tabular}{|l|l|c|c|c|c|}
\hline Parameters & Sources of variation & Sum square & Degree of liberty & Mean square & P-value \\
\hline Length & Zone & 25.73 & 1 & 12.86 & \\
\hline & Accession & 58.41 & 2 & 29.21 & \multirow{2}{*}{ P } \\
\hline Width & Zone & 40.35 & 1 & 20.17 & 31.02 \\
\hline & Accession & 62.05 & 2 & 22.52 \\
\hline Thickness & Zone & 45.04 & 1 & 48.19 \\
\hline & Accession & 96.38 & 2 & 19.77 \\
\hline Weight & Zone & 39.55 & 1 & 33.20 & \\
\hline & Accession & 99.59 & 2 & \\
\hline
\end{tabular}

Seeds harvested in the Sudano-Guinean zone had higher values of physical characteristics, with Motso 2 seeds generally exhibiting the larger sizes and Ndoutourou seeds the smaller one (figure 3). Seeds weight of our local castor seeds varied generally from $0.10 \pm 0.07 \mathrm{~g}$ for Ndoutourou accession in Soudano-sahelian zone to $0.70 \pm 0.18 \mathrm{~g}$ for Motso 2 accessions in Soudano-Guinean zone. Our seeds weight values fall within the range reported for other castor accessions in Senegal (0.22-0.60g) ${ }^{[27]}$. The smaller sizes of Ndoutourou accession is an added benefit for farmers at sowing period because their will have more quantities of seeds per $\mathrm{Kg}$ of sample.

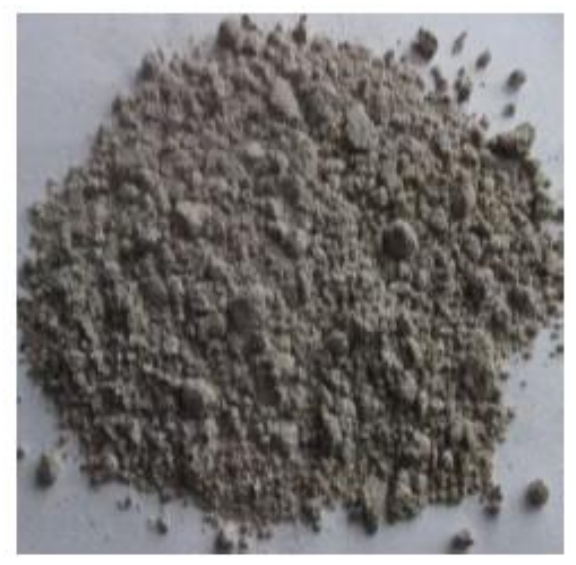

Figure1. Cake from Cameroonian Castor Bean

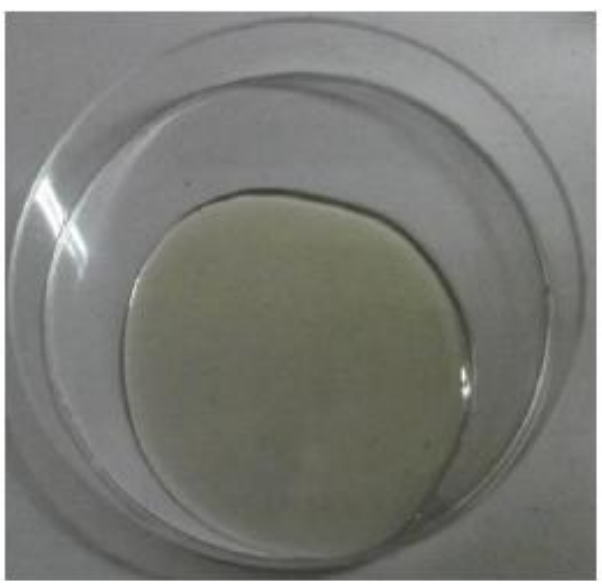

Figure2. Oil from Cameroonian Castor Bean 


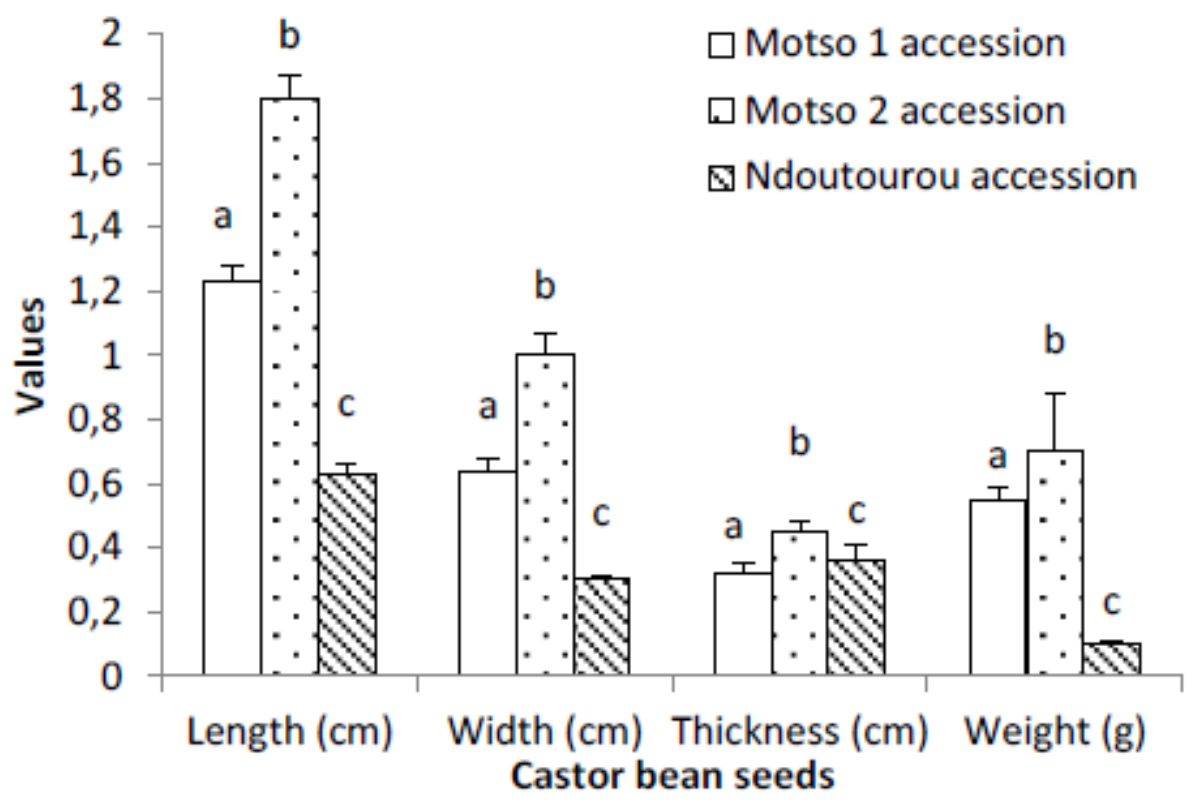

Figure3a. Ngaoundere in Sudano-Guinean Zone

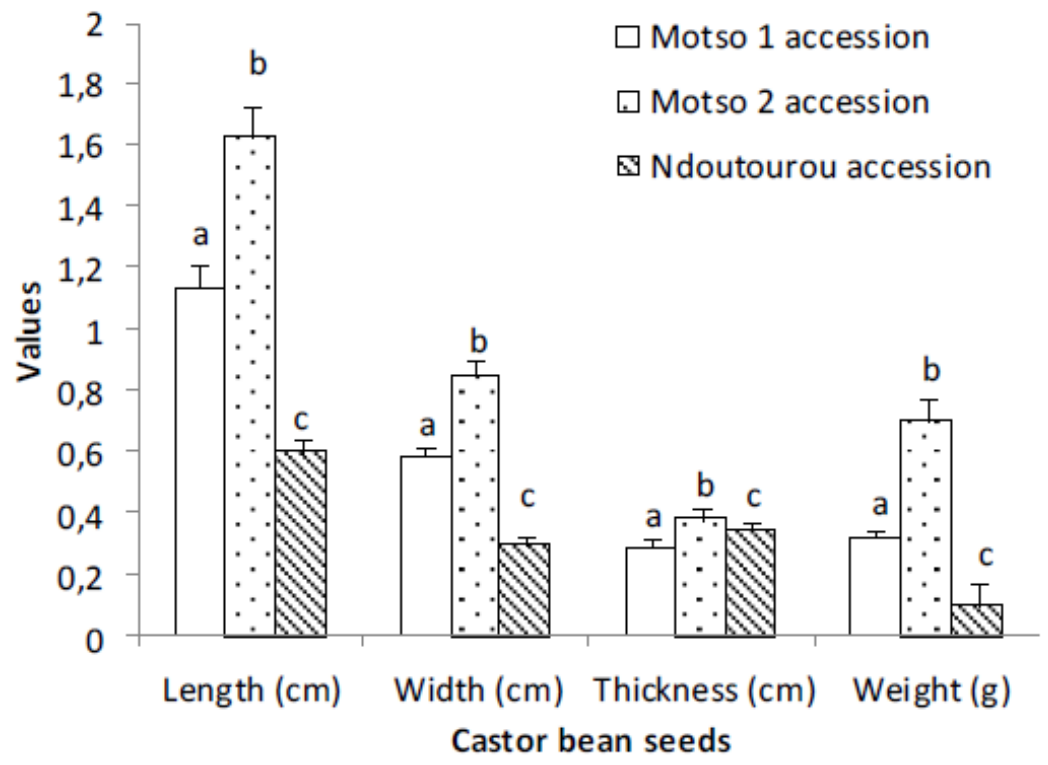

Figure3b. Maroua in Sudano-Sahelian Zone

Figure3. Physical Characteristics of seeds harvested in the two Agroecological Zones of Northern Cameroon

Note: Bar represented mean \pm Standard Deviation, $N=100$; Bars in Each Analyzed Variable Followed with Similar Letters are not significantly Different

\subsection{Oil and cake yields}

Generally the main composition of castor seeds (moisture, oil and cake content) were significantly $(\mathrm{p}<0.05)$ influenced by the accessions and the agro-ecological zone. Oil content of castor seeds from the Sudano-Sahelian zone $(50.23 \pm 2.44 \%)$ were systematically greater than oil content from those harvested in Sudano-Guinean zone $(45.95 \pm 1.47 \%)$, (figure 4). Ndoutourou accession had the lower value $(44.4 \pm 0.22 \%)$ of seeds oil content in Soudano-Guinean zone and the higher value $(53.6 \pm 0.30$ $\%)$ in Sudano-Sahelian zone. However, in the two agroecological zones, seeds from Ndoutourou accession had lower moisture content $(3.84 \pm 0.17 \%)$.

These results agree with those of ${ }^{[12]}$ who reported that seeds oil content from African castor bean ranges from $35.7 \%$ to $51.9 \%$. In addition, ${ }^{[5]}$ showed that seeds oil content from castor bean varied between 40 and $60 \%$ in commercial varieties. ${ }^{[28]}$ conducted research on adaptation and performance 
capacity of 19 castor bean genotypes in Mediterranean climate and reported that seed oil content depends on genotype but is also affected by environmental conditions and ranged from 44.5 to $54.2 \%$. ${ }^{[29]}$ had shown that castor seeds content $50 \%$ of lipid. As stated previously, castor bean is cultivated for it oil, and it productivity varies depending on many factors such as genotype, environment, seeds harvesting practices ${ }^{[19,28]}$.

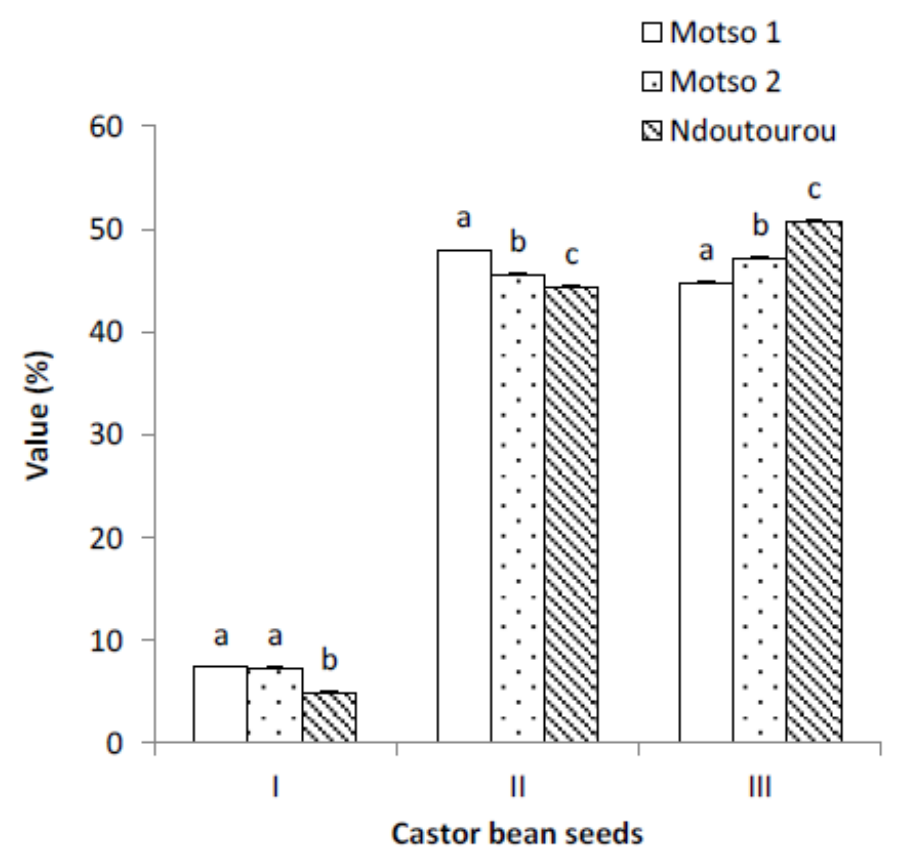

Figure4a. Ngaoundere in Sudano-Guinean Zone

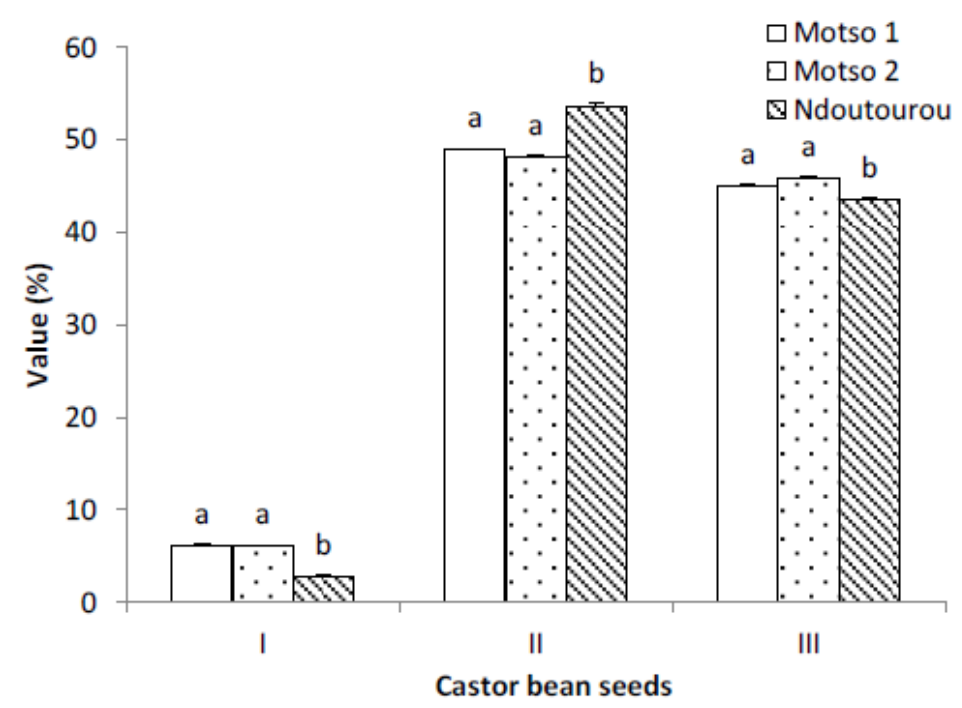

Figure4b. Maroua in Sudano-Sahelan Zone

Figure4. Composition of Castor Bean Seeds as Influenced by Agroecological Zones in Northern Cameroon Note I: Seeds Moisture Content; II: Seeds Oil Content; III: Seeds Cake Content

The values of two bands corresponding to a parameter and assigned with the same letter are not significantly different.

\subsection{Physicochemical Characteristics of Castor Bean Cake}

It appears from analysis of variance (ANOVA) of castor cake properties that all variables analyzed varied significantly $(\mathrm{p}<0.05)$ according to accessions and / or agro-ecological zones.

Table 2 shows some properties of castor cakes obtained in this study. These castor cakes are rich in phosphorus $(0.23 \pm 0.06 \mathrm{~g} / 100 \mathrm{~g} \mathrm{DM})$ and potassium $(1.48 \pm 0.25 \mathrm{~g} / 100 \mathrm{~g} \mathrm{DM})$ compared to other minerals (iron, sulfur, and chloride). Castor cake from Ngaoundéré Cameroon region was richer in 
organic matter and nitrogen (average $91.71 \pm 3.32$ and $4.19 \pm 0.51 \mathrm{~g} / 100 \mathrm{~g}$ DM respectively) than that from Maroua Cameroon region (average $87.06 \pm 2.38$ and $2.56 \pm 0.61 \mathrm{~g} / 100 \mathrm{~g}$ DM respectively). However, castor cake from Ngaoundere Cameroon region was poorer in potassium and phosphorus (average $1.42 \pm 0.26$ and $0.23 \pm 0.06 \mathrm{~g} / 100 \mathrm{~g} \mathrm{DM}$ respectively) than that from Maroua Cameroon region (average $1.54 \pm 0.22$ and $0.27 \pm 0.05 \mathrm{~g} / 100 \mathrm{~g}$ DM respectively). Nitrogen content of castor cake used varied from $1.8 \pm 0.16$ to $4.59 \pm 0.3 \mathrm{~g} / 100 \mathrm{~g}$ DM. These values are lower than those reported (6 to $9 \mathrm{~g} / 100 \mathrm{~g} \mathrm{DM})$ by ${ }^{[17]}$. In this study, phosphorus and potassium content varied from 0.09 \pm 0.008 to $0.21 \pm 0.01 \%$ and from $1.1 \pm 0.08$ to $1.71 \pm 0.06 \mathrm{mg} / 100 \mathrm{~g}$ DM respectively. Values of phosphorus and potassium content are lower than that reported by ${ }^{[16]}$ who shown that these values are in average 5.6 and $23.63 \mathrm{mg} / 100 \mathrm{~g}$ DM respectively for castor cake from Nigeria.

Table2. Properties of Castor Bean Cake according to Accessions and Agroecological Zones

\begin{tabular}{|l|l|l|l|l|}
\hline \multirow{2}{*}{ Parameters } & & \multicolumn{3}{|c|}{ Castor bean accessions } \\
\cline { 2 - 5 } & AZ & Motso 1 & Motso 2 & Ndoutourou \\
\hline Moisture $(\%)$ & SGZ & $8.83 \pm 0.12^{\mathrm{a}}$ & $9.00 \pm 0.081^{\mathrm{a}}$ & $8.23 \pm 0.54^{\mathrm{a}}$ \\
\hline $\mathrm{pH}$ & SSZ & $8.80 \pm 0.22^{\mathrm{a}}$ & $8.29 \pm 0.28^{\mathrm{a}}$ & $8.35 \pm 0.34^{\mathrm{a}}$ \\
\hline & SGZ & $6.16 \pm 0.12^{\mathrm{a}}$ & $3.75 \pm 0.04^{\mathrm{b}}$ & $5.56 \pm 0.04^{\mathrm{c}}$ \\
\hline Organic matter $(\mathrm{g} / 100 \mathrm{~g}$ DM) & SSZ & $6.23 \pm 0.05^{\mathrm{a}}$ & $5.41 \pm 0.01^{\mathrm{b}}$ & $6.43 \pm 0.01^{\mathrm{c}}$ \\
\hline & SGZ & $85.03 \pm 1.22^{\mathrm{a}}$ & $90.16 \pm 0.84^{\mathrm{b}}$ & $86.01 \pm 0.08^{\mathrm{a}}$ \\
\hline Nitrogen $(\mathrm{g} / 100 \mathrm{~g}$ DM) & SSZ & $87.19 \pm 0.71^{\mathrm{a}}$ & $93.08 \pm 0.38^{\mathrm{b}}$ & $94.87 \pm 0.51^{\mathrm{c}}$ \\
\hline & SGZ & $4.51 \pm 0.07^{\mathrm{a}}$ & $3.46 \pm 0.04^{\mathrm{b}}$ & $4.59 \pm 0.03^{\mathrm{a}}$ \\
\hline Phosphorus $(\mathrm{mg} / 100 \mathrm{~g}$ DM) & SSZ & $3.74 \pm 0.65^{\mathrm{a}}$ & $2.61 \pm 0.06^{\mathrm{b}}$ & $1.80 \pm 0.16^{\mathrm{c}}$ \\
\hline & SGZ & $0.03 \pm 0.01^{\mathrm{a}}$ & $0.14 \pm 0.01^{\mathrm{a}}$ & $0.09 \pm 0.01^{\mathrm{a}}$ \\
\hline Potassium $(\mathrm{mg} / 100 \mathrm{~g} \mathrm{DM})$ & SSZ & $0.21 \pm 0.01^{\mathrm{a}}$ & $0.10 \pm 0.01^{\mathrm{b}}$ & $0.20 \pm 0.01^{\mathrm{a}}$ \\
\hline Iron $(\mu \mathrm{g} / 100 \mathrm{~g} \mathrm{DM})$ & SGZ & $1.10 \pm 0.08^{\mathrm{a}}$ & $1.71 \pm 0.06^{\mathrm{b}}$ & $1.45 \pm 0.04^{\mathrm{c}}$ \\
\hline & SSZ & $1.56 \pm 0.12^{\mathrm{a}}$ & $1.25 \pm 0.04^{\mathrm{b}}$ & $1.66 \pm 0.12^{\mathrm{a}}$ \\
\hline Chloride $(\mu \mathrm{g} / 100 \mathrm{~g}$ DM) & SGZ & $21.00 \pm 1.00^{\mathrm{a}}$ & $35.00 \pm 1.00^{\mathrm{b}}$ & $35.00 \pm 1.00^{\mathrm{b}}$ \\
\hline & SSZ & $22.00 \pm 1.00^{\mathrm{a}}$ & $40.00 \pm 2.00^{\mathrm{b}}$ & $36.00 \pm 1.00^{\mathrm{b}}$ \\
\hline Sulfur $(\mu \mathrm{g} / 100 \mathrm{~g}$ DM) & SGZ & $8.00 \pm 1.00^{\mathrm{a}}$ & $6.00 \pm 1.00^{\mathrm{a}}$ & $3.00 \pm 1.00^{\mathrm{b}}$ \\
\hline & SSZ & $7.00 \pm 1.00^{\mathrm{a}}$ & $9.00 \pm 1.00^{\mathrm{b}}$ & $7.00 \pm 1.00^{\mathrm{a}}$ \\
\hline
\end{tabular}

Note: AZ: Agroecological zone; SGZ: Sudano-Guinean zone; SSZ: Sudano-Sahelian zone; DM: Dry Matter. Values of a line followed by the same letter are not significantly different.

\subsection{Physico-Chemical Properties of Castor Bean Oils}

Accession and agroecological zone influenced significantly $(\mathrm{p}<0.05)$ the physico-chemical properties (iodine value, acid value, saponification value, mass density and viscosity) of our local castor bean oils (Table 3). In both agro-ecological zones, physico-chemical properties of oil from Ndoutourou accession had intermediate values while oil from Motso 2 accession showed the highest acid and iodine values and Motso 1 accession oil presented smallest acid and iodine values. Saponification value and mass density from Motso 1 and Motso 2 accessions oils were respectively highest and lowest in the both harvested areas.

Table3. Physicochemical Properties of Castor Bean Accessions Oils Depending on Agroecological zone

\begin{tabular}{|c|c|c|c|c|}
\hline \multirow[t]{2}{*}{ Parameters } & \multirow[t]{2}{*}{$\mathbf{A Z}$} & \multicolumn{3}{|c|}{ Castor bean accessions } \\
\hline & & Motso 1 & Motso 2 & Ndoutourou \\
\hline \multirow[t]{2}{*}{ Iode value $\left(\mathrm{gI}_{2} / 100 \mathrm{~g}\right)$} & SGZ & $83,50 \pm 0,28^{\mathrm{a}}$ & $88,00 \pm 0,18^{b}$ & $85,10 \pm 0,27^{\mathrm{c}}$ \\
\hline & SSZ & $83,20 \pm 0,28^{\mathrm{a}}$ & $88,00 \pm 0,36^{\mathrm{b}}$ & $84,00 \pm 0,64^{\mathrm{a}}$ \\
\hline \multirow[t]{2}{*}{ Acid value $(\mathrm{mgKOH} / \mathrm{g})$} & SGZ & $2,70 \pm 0,09^{\mathrm{a}}$ & $3,80 \pm 0,06^{\mathrm{b}}$ & $3,10 \pm 0,07^{\mathrm{c}}$ \\
\hline & SSZ & $3,00 \pm 0,05^{\mathrm{a}}$ & $3,90 \pm 2,00^{b}$ & $3,80 \pm 1,52^{\mathrm{b}}$ \\
\hline \multirow{2}{*}{$\begin{array}{l}\text { Saponification } \\
(\mathrm{mgKOH} / \mathrm{g})\end{array}$} & SGZ & $178,90 \pm 0,76^{\mathrm{a}}$ & $172,62 \pm 0,76^{\mathrm{b}}$ & $175,80 \pm 1,32^{\mathrm{c}}$ \\
\hline & SSZ & $178,90 \pm 2,01^{\mathrm{b}}$ & $173,10 \pm 1,56^{\mathrm{a}}$ & $177,60 \pm 2,64^{b}$ \\
\hline \multirow[t]{2}{*}{ Mass density $(\mathrm{g} / \mathrm{ml})$} & SGZ & $0,95 \pm 0,01^{\mathrm{b}}$ & $0,89 \pm 0,01^{\mathrm{a}}$ & $0,92 \pm 0,01^{\mathrm{c}}$ \\
\hline & SSZ & $0,90 \pm 0,01^{\mathrm{a}}$ & $0,84 \pm 0,01^{\mathrm{c}}$ & $0,81 \pm 0,01^{\mathrm{b}}$ \\
\hline \multirow[t]{2}{*}{ Viscosity (mp.s) } & SGZ & $401.00 \pm 0.00^{\mathrm{a}}$ & $370.00 \pm 0.00^{b}$ & $386.00 \pm 0.00^{c}$ \\
\hline & SSZ & $377.00 \pm 0.00^{\mathrm{a}}$ & $340.00 \pm 0.00^{b}$ & $354.00 \pm 0.00^{\mathrm{c}}$ \\
\hline
\end{tabular}

Note: AZ: Agroecological zone; SGZ: Sudano-Guinean zone; SSZ: Sudano-Sahelian zone.

Values of a line followed by the same letter are not significantly different. 
Iodine value is a measure of unsaturation degree of the fatty acids of oil. Generally, iodine values of oil from Motso 1, Motso 2 and Ndoutourou accessions was $83.30 \pm 0.30 ; 88.00 \pm 0.30$ and $84.50 \pm$ $0.40 \mathrm{gI}_{2} / 100 \mathrm{~g}$ respectively. Iodine value of castor oil is relatively similar to that of oleate $85.6 \mathrm{gI}_{2} / 100$ $\mathrm{g}^{[30]}$. In fact, castor oil consists mainly of ricinoleic acid which is structurally similar to oleate know as cis-12-hydroxyoctadeca-9-enoic acid (hydroxylated fatty acid with 18 carbon atoms and a double bond). Our results corroborate several previous studies. Indeed, ${ }^{[31]}$ have shown that iodine value of castor oil varies between 82 and $88 \mathrm{gI}_{2} / 100 \mathrm{~g}$. Work carried on vegetable oils showed that overall, iodine value ranges from 10 (copra) to over 180 (fish oil) with an average of 80 to 130 for rapeseed, sunflower, soybean, castor and corn ${ }^{[32,33]}$. These iodine values are indicators of degree of unsaturation of castor oil ${ }^{[32]}$. More iodine value of oil is higher, more this oil will tend to go rancid and derived soap will spoil quickly. Conversely, more iodine value of oil is small, more oil will be stable and soap from this oil will be hard ${ }^{[34]}$. Therefore, the soap manufactured with oil from Motso 2 accession will spoil quickly because of its highest iodine value.

Acid value is mass of potassium expressed in milligrams $(\mathrm{mg})$ required to neutralize free acid contained in one gram $(1 \mathrm{~g})$ of fat ${ }^{[21]}$. Acid value of oils from Sudano-Guinean and Sudano-Sahelian zones was $3.16 \pm 0.07$ and $3.66 \pm 0.34 \mathrm{mg} \mathrm{KOH} / \mathrm{g}$ respectively. Our results on acid value are very different from those obtained by ${ }^{[31]}$ who showed that acid value of castor oil varies from 1 to $3 \mathrm{mg}$ $\mathrm{KOH} / \mathrm{g}$. Our very high values could be justified by process, including oil storage and drying which would have resulted in hydrolysis of triglycerides. It is also possible that quality of these oils vary with harvesting conditions. Determination of acid value allows us to assess the degree of alteration of oils by hydrolysis ${ }^{[35]}$. Furthermore, ${ }^{[36]}$ revealed that, acid value of edible oil must be less than or equal to $2 \mathrm{mg} \mathrm{KOH} / \mathrm{g}$ of fat. However, acid values of oils obtained in this study are much higher than this value. Thus, oils of castor bean accessions used are not edible. Our result is in accordance with studies of ${ }^{[37]}$ who showed that oil from Algerian castor bean is not safe to eat.

Saponification value is mass of potassium expressed in milligrams $(\mathrm{mg})$ required to neutralize the free fatty acids and to saponify the combined fatty acids contained in one gram (1g) of oil [21]. Saponification value of oils from Motso 1, Motso 2 and Ndoutourou accessions was $178.90 \pm 1.40$; $178.86 \pm 1.20$ and $176.70 \pm 1.98 \mathrm{mg} \mathrm{KOH} / \mathrm{g}$ respectively. Oil from Motso 2 accession had lowest saponification value and highest acid value while on the contrary; oil from Motso 1 accession had highest saponification value and lowest acid value. Generally, saponification value of our local castor oil was considerably lower than range of saponification value of common oils like palm kernel oil (230-254 mg KOH/g), cocoa butter (192-200 mg KOH/g), palm oil (190-209 mg KOH/g), cottonseed oil (189-198 mg KOH / g), soybean oil ( 189 -195 mg KOH/g), sunflower oil (188-194 mg KOH/g), corn oil (187-195 mg KOH/g), peanut oil (187-196 mg KOH/g) and olive oil (184-196 mg KOH/g) ${ }^{[30]}$. However, our results on this saponification value corroborate those of ${ }^{[31]}$ who showed that saponification value of castor oil ranges from 179 to 185 . In addition, ${ }^{[34]}$ reported that oils having saponification values ranging from 173.30 to $249.18 \mathrm{mg} \mathrm{KOH} / \mathrm{g}$ can be used for soap manufacture. Saponification values of our castor oil are present in this range. Therefore, these Cameroonian castor oils can be used for soap manufacture.

Mass density is defined as its weight per unit volume and viscosity is oil's resistance to flow. Castor oil from Sudano-Guinean zone was denser $(0.92 \pm 0.02 \mathrm{~g} / \mathrm{ml})$ and more viscous $(385 \pm 13 \mathrm{mPa} . \mathrm{s})$ than that from Sudano-Sahelian zone (respectively $0.85 \pm 0.03 \mathrm{~g} / \mathrm{ml}$ and $357 \pm 15 \mathrm{mPa} . \mathrm{s}$ ). In both study areas, oil from Motso 1 accession showed the higher value of density and viscosity. Density of castor oils studied (0.93 to $0.95 \mathrm{~g} / \mathrm{ml})$ was similar to that recently recorded by ${ }^{[36]}$ on oil from castor bean growing in Mexico. A positive and significant correlation was observed between density and viscosity of oils obtained in this work $(r=0.99 ; p<0.05)$. This result is in accordance with that of ${ }^{[37]}$ who observed that oil viscosity increases with its density. Values of viscosity from Cameroonian castor bean oil studied are similar to those previously reported on seven castor bean accessions cultivated in Mexico (from 200 to $600 \mathrm{mPa} . \mathrm{s}$ ) ${ }^{[36]}$. Density and viscosity are two properties that control flow ability of oil. More oil is viscous, more its ability to flow is slow. Oil viscosity is the most important parameter for oil lubrication systems ${ }^{[37]}$. As far as density and viscosity values of our castor bean oils are concerned, oils from seeds collected in Maroua area would flow faster than those from Ngaoundere region. Oil from Ndoutourou accession had lowest viscosity (363 mPa.s); therefore, this oil would have highest flow capacity. 


\subsection{Fatty Acids Composition of Castor Seed Oil from Different Accessions and Agroecological Zones}

Fatty acid composition of our castor oil is shown in Table 4. It is linoleic, oleic, palmitic, stearic and ricinoleic acids. Ricinoleic acid content is the highest. However, it is very small (62-67\%) compared to that of most marketed castor oils (90\%). This low value may be related to extraction solvent (hexane) used in the present work. Ricinoleic acid is more hydrophilic than most fatty acids (Gunstone, 2004). This is not the case with the work of ${ }^{[36]}$ who observed higher values in the same extraction conditions. Ricinoleic acid is called 12- hydroxyoleic acid. It is structurally similar to oleic acid with a hydroxy group at $\mathrm{C} 12$. Castor oil is more viscous, less soluble in hexane and soluble in ethanol (Gunstone, 2004). The industrial potential of castor oil releases on its ricinoleic acid content. Indeed, castor oil is primarily composed of ricinoleic acid and the presence of hydroxyl group and a double bond in the structure of this acid allows the oil to have multiple applications in chemical industry with many chemical reactions they can induce ${ }^{[38]}$.

Variations observed in different parameters in the two harvesting sites were linked to different climatic and soil conditions. Indeed, climate of Sudano-Guinean zone is wetter than that of SudanoSahelian zone. Soil in Sudano-Guinean zone has argillaceous texture, rich in organic matter and has acid $\mathrm{pH}$ while sandy texture, poor in organic matter and neutral soil $\mathrm{pH}$ was observed in SudanoSahelian zone. Observed variations can also be explained by the fact that these castor bean accessions would have different genotypic constitutions, but this need to be elucidated.

Table4. Fatty acids composition (\%) of castor seeds oil

\begin{tabular}{|c|c|c|c|c|}
\hline \multirow[b]{2}{*}{ Fatty acids } & \multirow[b]{2}{*}{$\mathbf{A Z}$} & \multicolumn{3}{|c|}{ Castor bean accessions } \\
\hline & & Motso 1 & Motso 2 & Ndoutourou \\
\hline \multirow{2}{*}{ Palmitic acid } & SGZ & 9,43 & 8,65 & 9,78 \\
\hline & SSZ & 9,18 & 8,75 & 10,36 \\
\hline \multirow[t]{2}{*}{ Oleic acid } & SGZ & 7,86 & 7,67 & 9,60 \\
\hline & SSZ & 7,66 & 7,15 & 8,70 \\
\hline \multirow[t]{2}{*}{ Ricinoleïc acid } & SGZ & 64,05 & 67,13 & 65,71 \\
\hline & SSZ & 66,93 & 63,50 & 62,51 \\
\hline \multirow[t]{2}{*}{ Linoleic acid } & SGZ & 4,30 & 4,46 & 3,15 \\
\hline & SSZ & 8,61 & 11,76 & 10,42 \\
\hline \multirow[t]{2}{*}{ Stearic acid } & $\begin{array}{l}\text { SGZ } \\
\text { CSZ }\end{array}$ & 10,01 & 7,57 & 8,57 \\
\hline & SSZ & 2,86 & 3,87 & 3,73 \\
\hline \multirow[t]{2}{*}{ Saturated fatty acid } & SGZ & 19,44 & 16,22 & 18,35 \\
\hline & SSZ & 17,79 & 20,51 & 20,78 \\
\hline \multirow[t]{2}{*}{ Unsaturated fatty acid } & $\begin{array}{l}\text { SUL } \\
\text { SS7 } 19\end{array}$ & 80,50 & 83,72 & 81,61 \\
\hline & & 82,17 & 79,15 & 78,54 \\
\hline
\end{tabular}

Note : AZ: Agroecological zone, SGZ: Sudano-Guinean zone; SSZ: Sudano-Sahelian zone

\section{CONCLUSION AND PERSPECTIVES}

In this present work, physical characteristics of seeds, seeds oil content and chemical properties of cake and oil from three castor bean accessions cultivated in Northern Cameroon have been outlined. The yield percentage of the seeds oil extraction and castor cake were evaluated as well as the castor bean accessions and environmental conditions influence over the seeds oil and castor cake's nature. Seeds oil content from Sudano-Guinean and Sudano-Sahelian zones are $44.35 \pm 0.22$ to $53.65 \pm 0.30$ $\%$ respectively. Nitrogen content of castor cake obtained varies from $1.8 \pm 0.16$ to $4.59 \pm 0.3 \%$. It is rich in potassium $(1.48 \pm 0.25 \%)$ and phosphorus $(0.23 \pm 0.06 \%)$ compared to other mineral (iron, sulfur and chloride). Iodine and acid values of Cameroonian castor oils studied range from 83.20 \pm 0.28 to $88.00 \pm 0.18 \mathrm{gI}_{2} / 100 \mathrm{~g}$ and from $2.70 \pm 0.90$ to $3.90 \pm 0.10 \mathrm{mg} \mathrm{KOH} / \mathrm{g}$. The ricinoleic acid content (62$67 \%$ ) is higher than other fatty acid content of oil obtained in this study. It comes from this results that oil from our local castor bean can play a role in the chemical industries market while the cake can be useful in agriculture as biological fertilizer or as folder for animal nutrition, but this need further investigation, as well as different genotypic constitution of our castor bean accessions. 


\section{REFERENCES}

[1] Kirtikar K. R., Basu B. D. 1987. Indian medicinal plants. $2^{\text {nd }}$ ed. Dehradun, India: International book distributor; 1987 pp. 2274-2277.

[2] Tchuenteu T. L., Megueni C., Tchobsala and Njintang Y. N., 2013a. Effect of Intercropping Systems of Castor Bean, Maize and Common bean on their Growth and Seeds Yield in the Soudano Guinea Zone of Cameroon. Journal of Agricultural Sciences and Technology B 3(8): 582-590.

[3] Madail J.C.M., Belarmino L.C. and Neutzling D. M. 2007. AspectosEconômicos da mamona. Sistemas de Produção. Embrapa, 11. ISSN 1806-9207.

[4] Evangelista A.R., Abreu J.G. and Per A.J. 2004. Avaliação da composição química de tortas de mamona e amendoimobtidaspordiferentesmétodos de extração de óleo. In: Congresso Brasileiro de Mamona, 1, 2004. Campina Grande. Anais...Campina Grande: Embrapa Algodão. (2004) (CD-Rom).

[5] Weiss E. A. 2000. Castor. In Oilseed Crops. $2^{\text {nd }}$ Edition, Blackwell Scientific Ltd, Oxford. 1352.

[6] Weiss E. A. 1983. Oilseed Crops. Longman, New York. 660 pp.

[7] Ogunniyi, D.S. 2006. Castor Oil: A vital industrial raw material. Bioresource Technology 97: 1086-1091.

[8] Bojean A. 1991. Le Ricin: Une Culture Pour la Chimie. Gallileo, Paris. 101 p.

[9] Borch-Jensen C., Jensen B., Mathiasen K. and Mollerup J. 1997. Analysis of Seed Oil from Rcinus communis and Dimorphoteca pluvialis by Gas and supercritical fluid chromatography. JAOCS 74 (3).

[10] Conceicao M. M., Candeia R. A., Silva F. C., Bezerra A. F. Fernandes Jr. V. J. and Souza A. G. 2007. Thermoanalytical characterization of castor oil biodieselm. Renewable and Sustainable Energy Review 11 : 964-975.

[11] Foglia T. A., Jones K. C. and Sonnet P. E. 2000. Selectivity of lipases: isolation of fatty acids from castor, coriander, and meadowfoam oils. European Journal of Lipid Science Technology 102(10): 612-617.

[12] Gupta S.S., Hilditch T. P. and Riley J. P. 1951. The fatty Acids and Glycerides of Castor Oil. Journal of the Science of Food and Agriculture 2 (6): 245-251.

[13] Mutlu H. and Meier M., 2010. Castor oil as arenewable resource for the chemical indus-try.Eur J Lipid Sci Technol 112 : 10-30.

[14] Puthli M. S., Rathod V. K. and Pandit A. B. 2006. Enzymatic Hidrolisis of Castor Oil: Process Intensification Studies. Biochemical Engineering Journal 1-11.

[15] Severino L.S. 2005. O que sabemos sobre a torta de mamona. Campina Grande: Embrapa Algodão, 2005. (Documentos, 134).

[16] Annongu A., Azor and Joseph J. K. 2008. Proximate analysis of castor seeds and cake. Journal of Applied Sciences 12 (1): 39-41.

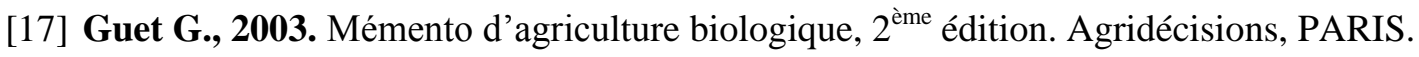

[18] Tchobsala, Amougou A., Abou A. A. N., Wey J. 2009. Inventaire des variétés de Ricinus comminus L. dans la zone cotonnière du Cameroun P. 81. In Biosciences and foods security.16 ème conférence annuelle du Comité Camerounais des Biosciences, $105 \mathrm{p}$.

[19] Tchuenteu T. L., Megueni C., Njintang Y. N. 2013b. A study of the variability for grain and oil yield and yield related traits of castor beans accessions in two savannah agro-ecological zones of Cameroon. International Journal of Biosciences 3(8) : p. 251-263.

[20] Achten W. M. J., Verchot L., Franken Y. J., Mathijis E., Singh V. P., Aerts R. and Muys B. 2008. 'Jatropha biodiesel production and use'. Biomass and Bioenergy (32): 1063-1084.

[21] AFNOR (Association Française de Normalisation), 1981. Recueil de normes françaises. Corps gras, graines oléagineuses, produits dérivés.

[22] UICPA (Union International de Chimie Pure et Appliquée). 1979. Méthodes d'analyses des matières grasses et dérivées. $6^{\mathrm{e}}$ éd. Lavoisier, Tec. et Doc., Paris. 
[23] AOAC, 1990. In Official methods of analysis.K Helrich.(Ed.), Fifteenth edition.Virginia (USA) pp. 963-964.

[24] Devani M.B., Shishoo J.C.,. Shal S.A and Suhagia B.N. 1989. Spectrophotometrical method for determination of nitrogen in Kjeldahl digest. JAOAC 72: 953-956

[25] AFNOR. 1982. Recueil des normes françaises des produits dérivés des fruits et legumes. Jus de fruits. $1^{\text {ère }}$ éd., Paris la défense (France).

[26] AOAC (Association of Official Analytical Chemists), 1975. Methods of analysis of the association of Official Analytical Chemists, $10^{\text {th }}$ ed. AOAC, Washington, DC.

[27] Diallo B., Samba S. A. N., Sane D. and Diop T. 2013. Effet du chlorure de sodium sur la germination de graines de Ricinus communis L. International Journal of Biological and Chemical Science 7(4): 1534-1544.

[28] Koutroubas S. D., Papakosta D. K. and Doitsinis A. 1999. Adaptation and yielding ability of castor plant (Ricinus communis L.) genotypes in a Meditarranean climate. European Journal of Agronomy 11 : 227-237.

[29] Pina M., Severino L.S., Beltrão N.E.M., Villeneuve P. \&Lago R. 2005. Novas alternativas de valorização para dinamizar a cultura da mamona no Brasil. Cadernos de Ciência e Tecnologia, 22, 453-462.

[30] Gunstone, F. D. 2004. Rapeseed and Canola Oil: Production, Processing, Properties and Uses. Blackwell Publishing Ltd., CRC Press, Boca Raton, USA, PP.222.

[31] Charlier D and Chily P. 2004. Polymerisation method by dielectric heating of unsaturated fatty acid,unsaturated fatty acidesters, unsaturate dihydrocarbons or unsaturated derivatives of said products. Technical disclosure bulletin 18(1):1975- 1986.

[32] Lambert J. 2005. Les huiles végétales : 2000 plantes oléagineuses répertoriées. Institut Français des Huiles Végétales Pures. 23 p. http://institut.hvp.free.fr

[33] Marty G. 2005 Rapport du bilan des gaz à effet de serre de production des biocarburants. ADME/DIREN priice waterhouse coopers Decembre 2002. Édition tournesol. Nov 2005. France. $93 \mathrm{p}$.

[34] Eke U. B., Dosumu O. O., Oladipo E. et Agunbiade F. O., 2004. Analysis of locally produced soap using Sheabutter oil (SBO) Blended with Palm -Kernel (PKO). Nigerian Journal of Science. 38:19-24.

[35] Maroyi A. 2007. Ricinus communis L. In : van der Vossen, H.A.M. and Mkmilo, G.S, PROTA 14: Vegetable oil/Oléagineux, Wageningen, Pays Bas, pp. 12-18.

[36] FAO/OMS. 2013. Comité du codex sur les matières grasses. Vingt troisième session Langkawi (Malaisie), 25 février-1er mars 2013 document de travail sur les huiles pressées à froid. CX/FO 13/23/6.

[37] Alloune R., Liazid A. and Tazerout M. 2012. Etudes comparatives de deux plantes oléagineuses locales pour la production du biodiesel en Algérie. Revue des Energies Renouvelables SIENR'12 Ghardaïa. P. 19-22.

[38] Perdomo F. A., Acosta-Osorio A. A., Herrera G., Vasco-Leal F. J., Mosquera-Artamonov J. D., Beatriz Millan-Malo and Rodriguez-Garcia M. E. 2013. Physicochemical characterization of seven Mexican Ricinus communis L. seeds and oil content. Biomass and Bioenergy 48: 17-24.

[39] Bernat E., Jordi-Roger R., Grau B., Antoni R. and Rita P. 2012. Temperature dependent of density and viscosity of vegetable oil. Biomass and Bioenergy 42: 164-171.

[40] Flemming N., Banana H. and Jan de Jongh, 2011. Castor (Ricinus communis L.) Potentiel de ricin pour la production de bio-carburant, Préparé par la Fondation FACT plante de ricin. 